\title{
Adsorption of biosolids and their main components on chalcopyrite, molybdenite and pyrite: Zeta potential and FTIR spectroscopy studies
}

\author{
Lorenzo Reyes-Bozo $^{\mathrm{a}, *}$, Mauricio Escudey ${ }^{\mathrm{b}}$, Eduardo Vyhmeister ${ }^{\mathrm{c}}$, Pablo Higueras ${ }^{\mathrm{d}}$, \\ Alex Godoy-Faúndez ${ }^{\mathrm{e}}$, José Luis Salazar ${ }^{\mathrm{f}}$, Héctor Valdés-González ${ }^{\mathrm{a}}$, Germán Wolf-Sepúlveda ${ }^{\mathrm{g}}$, \\ Ronaldo Herrera-Urbina ${ }^{\mathrm{h}}$
}

${ }^{a}$ Departamento de Ciencias de la Ingeniería, Facultad de Ingeniería, Universidad Andres Bello, Sazié 2315, Santiago, Chile

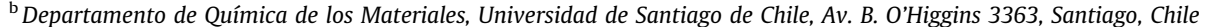

${ }^{\mathrm{c}}$ Departamento de Ciencias de la Energía y Mecánica, Universidad de las Fuerzas Armadas - ESPE sede Latacunga, Ecuador

d Departamento de Ingeniería Geológica y Minera, Universidad de Castilla-La Mancha, Plaza M. Meca 1, 13400 Almadén, Ciudad Real, Spain

e Facultad de Ingeniería, Universidad del Desarrollo, Av. La Plaza 680, Santiago, Chile

${ }^{\mathrm{f}}$ Departamento de Ingeniería Química, Universidad de Santiago de Chile, Casilla 10233, Santiago, Chile

${ }^{\mathrm{g}}$ Subgerencia Gestión de Procesos, Gerencia de Operaciones, Essbio S.A., Diagonal Pedro Aguirre Cerda 1129, Concepción, Chile

${ }^{\mathrm{h}}$ Departamento de Ingeniería Química y Metalurgia, Universidad de Sonora, Hermosillo, Mexico

\section{A R T I C L E I N F O}

\section{Article history}

Received 17 December 2014

Revised 16 April 2015

Accepted 27 April 2015

\section{Keywords:}

Chalcopyrite

Molybdenite

Zeta potential

Biosolids

Humic acids

\begin{abstract}
A B S T R A C T
Zeta potential measurements were used to assess the electrokinetic characteristics of chalcopyrite, molybdenite and pyrite in the presence of biosolids and their main components (humic acids, glucose and serum albumin) as well as a commercial collector (Aero 6697). Fourier transform infrared spectroscopy (FTIR) was then used to gain a deeper understanding of the interaction of these compounds with these sulfide minerals. It aims to achieve a better understanding of the surface chemistry of sulfide-water interfaces that improve froth flotation at industrial scale in the step of copper sulfide ore concentration. Zeta potential results show that hydrogen and hydroxide ions are potential determining ions for each sulfide mineral studied. The addition of $50 \mathrm{~g} / \mathrm{t}$ biosolids or all the other chemicals used in this investigation shift the isoelectric point of chalcopyrite. Under the same conditions, only humic acid significantly affects the zeta potential of molybdenite, making it more negative in the $\mathrm{pH}$ range investigated, and shifting its isoelectric point about $6 \mathrm{pH}$ units. These compounds seem to have a poor affinity with pyrite surfaces because their zeta potential is slightly modified. FTIR spectroscopy characterization shows that biosolids and their main components can interact with chalcopyrite, molydenite and pyrite surfaces through a complex mechanism involving chemical or physical linkages. The results reported here seem to indicate that biosolids may be used as new environment-friendly froth flotation agents to concentrate copper and molybdenum sulfide minerals.
\end{abstract}

(c) 2015 Elsevier Ltd. All rights reserved.

\section{Introduction}

Both copper oxides and sulfides ores have been concentrated by froth flotation in Chile and throughout the world for many years. However, the concentration of copper sulfides ores is by far more intensive than that of copper oxides (Bulatovic, 2007; Cochilco, 2012). In copper sulfides ores, the main valuable copper sulfide mineral is chalcopyrite $\left(\mathrm{CuFeS}_{2}\right)$. Another valuable sulfide they often contain is molybdenite $\left(\mathrm{MoS}_{2}\right)$. However, these ores also

\footnotetext{
* Corresponding author. Tel.: +56 2 26618456; fax: +56 226615894

E-mail address: 1reyes@unab.cl (L. Reyes-Bozo).
}

contain varying amounts of non-valuable and undesired pyrite $\left(\mathrm{FeS}_{2}\right)$ (Bulatovic, 2007).

According to statistics from Cochilco (Chilean Copper Commission, 2013), in the year 2012 the copper mining operations had an annual handling capacity to concentrate 450 million tonnes of copper sulfide ore by froth flotation, yielding 3.7 million tonnes of fine copper. It is projected that for the year 2021, the installed capacity to process copper sulfide ores will increase to 1200 million tonnes and fine copper production will reach 6.8 million tonnes. However, during the period 2004-2013, the copper grades of Chilean copper sulfide ores decreased from $1.16 \% \mathrm{Cu}$ to $0.90 \% \mathrm{Cu}$ (Cochilco, 2013). Therefore, the projected copper production and the decreased copper grades of copper sulfides ores will result in 
a greater consumption of water, energy and chemical reagents. In particular, the consumption of collectors, frothers and modifiers in froth flotation is increasing because higher amounts of low-copper grade ore are processed. Consequently, the evaluation of new environment-friendly froth flotation agents, such as biosolids and their main components, may help to make froth flotation plants more efficient and reduce their damage to the environment.

The typical chemical composition of stabilized biosolids is highly diverse; however, their main components are humic substances (fulvic and humic acids), proteins (aminoacids), polysaccharides (sugars) and to a lesser extent nucleic acids (Baham and Sposito, 1982; Escudey et al., 2004; Eskicioglu et al., 2006; Parnaudeau and Dignac, 2007; Ras et al., 2008; Reyes-Bozo et al., 2011a). Therefore, biosolids, humic acids, $\alpha$-D-glucose and bovine serum albumin were used to evaluate the interactions of biosolids with sulfide minerals.

Electrokinetic studies of chalcopyrite, molybdenite and pyrite are important for the development of their effective separation by froth flotation during the concentration of copper sulfide ores. Compared with the well-known electrokinetic behavior of oxides, that of sulfide minerals is less well understood, and different isoelectric points (IEP) are reported in the literature. In the case of chalcopyrite, for example, an IEP at around $\mathrm{pH} 3.0$ has been reported by Rath et al. (2001), but Mitchell et al. (2005) have reported an isoelectric point at $\mathrm{pH} 5.5$ for a chalcopyrite sample containing 65\% chalcopyrite. For pyrite, Mitchell et al. (2005) and Patra and Natarajan (2006) have reported an isoelectric point at a pH between 2 and 2.5. Liu and Huang (1992) report that pyrite and molybdenite have an isoelectric point at $\mathrm{pH}$ values smaller than 3.0. The main reason for these inconsistencies is that a number of factors affect the electrokinetic behavior of sulfide minerals such as surface oxidation, lattice defects, cationic charge, photoirradiation and sample pretreatment (Fuerstenau and Mishra, 1980; Liu and Huang, 1992).

The aim of this research work was to delineate the effect of the interaction of biosolids and their main components on the electrokinetic characteristics of chalcopyrite, molybdenite and pyrite, using zeta potential measurements and Fourier transform infrared spectroscopy (FTIR) analysis. A better understanding of the surface chemistry of these sulfide minerals in the presence of biosolids and their main components may aid to make the industrial froth flotation of copper sulfides ores a more efficient and environment-friendly process.

\section{Materials and methods}

\subsection{Chalcopyrite, molybdenite and pyrite samples}

Chalcopyrite and pyrite mineral specimens were obtained from División Los Bronces (Anglo American, Chile), while a molybdenite concentrate sample was supplied by Molymet (Santiago, Chile). Samples of chalcopyrite and pyrite were ground in an IKA MF 10 Basic Microfine grinder apparatus. The ground mineral samples were then sieved for 6 min in a Rotap (W.S. Tyler Model Number RX-29-10) to obtain $75-106 \mu \mathrm{m}(-140+200$ mesh $)$ size fractions for Fourier transform infrared spectroscopy (FTIR) analysis and zeta potential measurements.

The mineralogical compositions of chalcopyrite, molybdenite, and pyrite samples were determined by an accredited laboratory (Laboratory MAM Ltda., Chile) following standard methods according to Gaines et al. (1997). Elemental chemical analyses were also performed for each of these mineral samples. The metal contents were determined by atomic absorption spectrophotometry with a Perkin Elmer Analyst 300 apparatus. Dumas combustion method was used to quantify sulfur contents. Further, X-rays diffraction
(XRD) analyses were performed with a Siemens D5000 diffractometer $\left(\lambda\right.$ : $1.5406 \AA$, $0.02^{\circ}$ each $2 \mathrm{~s}$, temperature $24{ }^{\circ} \mathrm{C}$ ). Diffractograms were interpreted through Diffract Plus v.15 software and JCPDS-ICDD (2009), PDF-2 database.

The elemental chemical analysis of chalcopyrite reports $21.5 \%$ copper, $30.2 \%$ iron, $26.2 \%$ sulfur and $0.01 \%$ molybdenum. Mineralogical analyzes indicate that the chalcopyrite sample contains $65.4 \%$ chalcopyrite, $13.4 \%$ pyrite, $9.9 \%$ magnetite and $10.2 \%$ nonmetallic gangue minerals. The diffractogram of the chalcopyrite sample (not included) shows that chalcopyrite $\left(\mathrm{CuFeS}_{2}\right)$ and pyrite $\left(\mathrm{FeS}_{2}\right)$ are the main components of this mineral sample. Quartz $\left(\mathrm{SiO}_{2}\right)$ and iron oxide $\left(\mathrm{Fe}_{3} \mathrm{O}_{4}\right)$ are also detected in this diffractogram.

The elemental chemical analysis of molybdenite reports $0.2 \%$ copper, $0.6 \%$ iron, $61.4 \%$ sulfur and $37.7 \%$ molybdenum. The molybdenite sample was found to contain $98.7 \% \mathrm{MoS}_{2}$, and minor amounts of chalcopyrite $(0.6 \%)$ and nonmetallic minerals $(0.7 \%)$. XRD shows only the presence of molybdenum sulfide $\left(\mathrm{MoS}_{2}\right)$.

The elemental chemical analysis of pyrite reports $0.2 \%$ copper, $46.8 \%$ iron, $47.5 \%$ sulfur and $0.01 \%$ molybdenum. The purity of the pyrite sample was found to be $95.8 \%$, with minor contents of chalcopyrite $(0.5 \%)$ and nonmetallic minerals (3.2\%). The diffractogram of pyrite indicates that this mineral is the main component of this sample, with minor amount of quartz $\left(\mathrm{SiO}_{2}\right)$.

\subsection{Biosolids and their main components}

Biosolids used in this research work were obtained from a wastewater treatment plant (Essbio, Concepción, Chile) where the biological removal of organic load was performed using activated sludge technology. This biosolids sample was ground in a mortar, and then homogenized and sieved to a fraction smaller than $1 \mathrm{~mm}$. Biosolids samples were physically and chemically analyzed in certified laboratories (Análisis Ambientales and Laboratorio de Suelos y Análisis Foliar, PUCV). Biosolids contained $66.5 \%$ organic matter, and their aqueous suspensions (1:2.5 solid:water ratio) had a $\mathrm{pH}$ of 7.8 and an electrical conductivity of $7.2 \mathrm{mS} / \mathrm{cm}$. The total content of $\mathrm{Cu}=280.8, \mathrm{Fe}=5652.2$, $\mathrm{Mo}=2.6$ and $\mathrm{P}=13148.3$, expressed as $\mathrm{mg} / \mathrm{kg}$. All metal contents were determined by atomic absorption spectrophotometry with a Perkin Elmer Analyst 300 apparatus. The content of humic substances, quantified by standard method (Sadzawka et al., 2006), was $10.6 \%$ fulvic acid, $2.5 \%$ humic acids and $27.8 \%$ humins.

$\alpha$-D-glucose and bovine serum albumin (both from Aldrich) were used as sugars and protein representatives contained in the biosolids. A commercial sodium salt of humic acid (Aldrich) was used as representative of humic substances present in the biosolids. According to Pandey et al. (1999), humic acid has a characteristic composition of $44.67 \%$ organic carbon, $5.87 \%$ hydrogen, $4.88 \%$ total nitrogen, $43.9 \%$ oxygen, and $0.58 \%$ ash with a total acidity of $12.3 \mathrm{~mol} / \mathrm{kg}$. The concentration of functional groups such as $\mathrm{COOH}$ and phenol $(-\mathrm{OH})$ was 4.1 and $8.2 \mathrm{~mol} / \mathrm{kg}$, respectively.

\subsection{Zeta potential measurements}

The interaction of the surfaces of chalcopyrite, molybdenite and pyrite with biosolids and their main components (i.e., sugars, proteins and humic substances) was investigated through zeta potential measurements. For the zeta-potential measurements, $0.2 \mathrm{~g}$ of sulfide mineral was dispersed in $200 \mathrm{~mL}$ of $1.0 \mathrm{mM} \mathrm{KNO}_{3}$ solution and sonicated for two minutes. Then, the suspension was conditioned for five minutes upon the addition of the biosolids, their main components or chemical collector to be tested, at a concentration of $50 \mathrm{~g} / \mathrm{t}$. Typical collector dosage used at plant-scale operations range between 10 and $100 \mathrm{~g} / \mathrm{t}$ (Thomas, 2010). Then, a 
dosage of $50 \mathrm{~g} / \mathrm{t}$, within the range used in industrial operations, was first selected for zeta potential experiments.

The ionic strength of these dispersions was maintained constant at $1.0 \mathrm{mM}$ with $\mathrm{KNO}_{3}$. All electrokinetic measurements were made using an auto-sampler with a zeta-meter (Zeta Meter, Inc., USA). The $\mathrm{pH}$ was adjusted by adding $0.1 \mathrm{M} \mathrm{KOH}$ or $0.1 \mathrm{M} \mathrm{HNO}_{3}$ solutions. The reported $\mathrm{pH}$ corresponds to the measurements obtained after the overall conditioning process. Reported zeta potential values are the average of at least 20 measurements. The reliability of the Zeta Meter apparatus was periodically verified by calibration against a standard test colloid (Min-U-Sil, colloid supplied by the manufacturer, Zeta Meter, Inc., USA). Min-U-Sil maintained a constant zeta potential of $-56 \pm 3 \mathrm{mV}$ over a wide range of concentration when suspended in distilled water. The standard deviation of these measurements was lower than $5 \%$.

As a positive control, an industrial chemical collector reagent (Aero 6697 promoter, Cytec), was used for comparison. This collector, an alkyl monothiophosphate, has a specific gravity of $1.14\left(@ 20^{\circ} \mathrm{C}\right), \mathrm{pH}>13$, viscosity of $15-35$ (cps @ 20 $\left.{ }^{\circ} \mathrm{C}\right)$, and it is completely soluble in water. Cytec reports that a common dose of $5-100 \mathrm{~g} / \mathrm{t}$ of Aero 6697 is used to concentrate copper and precious metals (Thomas, 2010).

\subsection{Preparation of mineral samples for characterization with FTIR spectroscopy}

For Fourier transform infrared spectroscopy (FTIR) analyses, $0.5 \mathrm{~g}$ of chalcopyrite, molybdenite, or pyrite was dispersed in $5 \mathrm{~mL}$ of double-distilled water. Then, $50 \mathrm{~g} / \mathrm{t}$ of Aero 6697 promoter, biosolids, $\alpha$-D-glucose, bovine serum albumin or sodium salt of humic acid were added and the suspension conditioned for $30 \mathrm{~min}$ under agitation at $250 \mathrm{rpm}$. The $\mathrm{pH}$ was then adjusted to 10 with $\mathrm{NaOH}$ aliquots and the suspension conditioned for $24 \mathrm{~h}$ under agitation at $250 \mathrm{rpm}$. Mineral control samples were conditioned following the described procedure, but without the addition of biosolids or chemical compounds to be tested as possible flotation collectors. At the end of the conditioning period, all mineral samples were washed 5 times with double-distilled water to remove physically adsorbed chemicals on the surfaces of the sulfide minerals investigated. Washing involved $5 \mathrm{~min}$ sonication and $20 \mathrm{~min}$ of centrifugation at $2500 \mathrm{rpm}$. All samples were dried under vacuum for $48 \mathrm{~h}$.

Pellets for FTIR spectroscopy analysis were prepared by mixing $1 \mathrm{mg}$ of the mineral sample to be tested with $100 \mathrm{mg}$ of dry $\mathrm{KBr}$ ( $\mathrm{KBr}$ spectroscopic, Merck). The samples were analyzed in triplicate on a Bruker Vector 22, reporting the region between 4000 and $500 \mathrm{~cm}^{-1}$, using 16 scans every $10 \mathrm{~s}$.

A deconvolution process, by using Gaussian curves, was performed in the sulfates regions to obtain a measure of the concentration of sulfates before and after treatments on each experimental run. The software Igor 5.0.2.0 was used for this task. This measure was used to calculate percentage of signals modified on each treated sample.

\section{Results and discussion}

\subsection{Zeta potential}

The zeta potential of chalcopyrite, molybdenite and pyrite minerals was first determined as a function of $\mathrm{pH}$, open to the atmo-

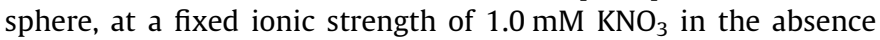
of biosolids or their main components, and these results are presented in Fig. 1. This figure shows that the zeta potential of these minerals depends on the $\mathrm{pH}$ : it is positive at low $\mathrm{pH}$ values, goes through zero and becomes negative as the $\mathrm{pH}$ increases.

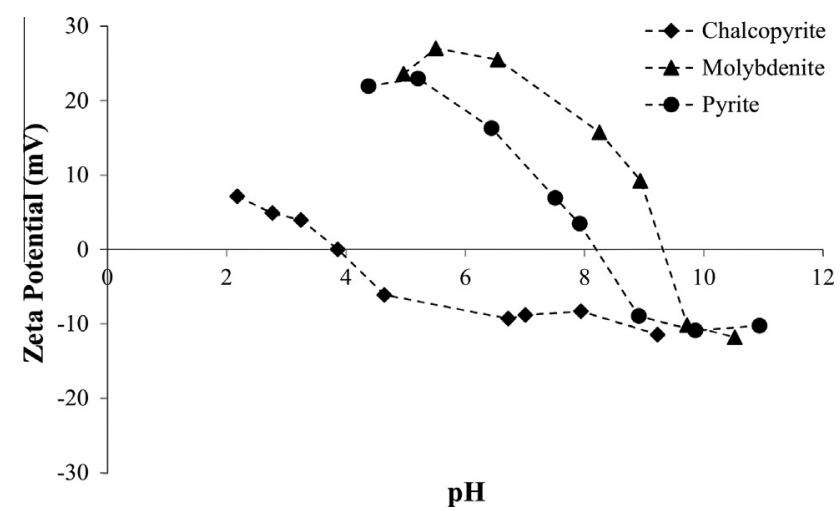

Fig. 1. The zeta potential of chalcopyrite, molybdenite and pyrite as a function of $\mathrm{pH}$ at constant ionic strength of $1.0 \mathrm{mM} \mathrm{KNO}_{3}$. Figure shows the average value $(n \geqslant 20)$ and standard error is within the symbols. Lines not necessarily represent linear trends.

Therefore, hydrogen and hydroxide ions are potential determining ions for these sulfide minerals. According to the zeta potential results plotted in Fig. 1, the isoelectric point (IEP) of chalcopyrite occurs at $\mathrm{pH} 3.9$, that of molybdenite at $\mathrm{pH} 9.1$, and that of pyrite at $\mathrm{pH} 8.1$.

The IEP of the chalcopyrite sample used in this investigation is close to the value reported by other researchers, namely around $\mathrm{pH}$ 3.0 (Rath et al., 2001). However, Mitchell et al. (2005) have reported an isoelectric point at $\mathrm{pH} 5.5$ for a chalcopyrite sample containing $65 \%$ chalcopyrite. This chalcopyrite content is equal to that of the sample used in this research work. In addition to the purity of the mineral sample, it is well known that the IEP reported for the same sulfide mineral depends on factors such as surface oxidation, pre-treatment and preparation of the sample (Steger and Desjardins, 1978; Sutherland and Wark, 1955). Das et al. (1997), have also reported a significant effect of the solid:liquid ratio on the IEP of freshly ground and aged chalcopyrite samples.

The isoelectric point of natural molybdenite has been reported to occur in the $\mathrm{pH}$ range between 1.5 and 4.0 (Healy and Fuerstenau, 2007; Liu and Huang, 1992). Synthetic molybdenite also shows an IEP within this pH range, namely 2.8 (Gil-Llambías et al., 1984). Because the IEP of sulfides depend on the source of the mineral, the electrolyte and the method (i.e., electrophoretic mobility, streaming potential, etc.) used, and the preparation of the sample, among other factors, it is not surprising that the IEP of the molybdenite concentrate used in this research work (at $\mathrm{pH}$ 9.1 ) is in sharp disagreement with the values reported by other researchers for non-floated samples of molybdenite.

Mitchell et al. (2005), Patra and Natarajan (2006), and Reyes-Bozo et al. (2011b) have reported that the isoelectric point of pyrite occurs between pH 2 and pH 2.5. Liu and Huang (1992) have reported that pyrite has an isoelectric point at $\mathrm{pH}$ values smaller than 3.0. Fuerstenau and Mishra (1980), however, reported that the isoelectric point of pyrite occurs at $\mathrm{pH} 7$ when the mineral sample is conditioned open to the atmosphere for a period between $1 \mathrm{~h}$ and $24 \mathrm{~h}$ in the presence of two different concentrations of $\mathrm{NaNO}_{3}$. Earlier, Gaudin and Sun (1946) reported an isoelectric point at pH 6.4 for pyrite. These different IEP of pyrite, as well as the one found in this research work (IEP at $\mathrm{pH} 8.1$ ), result from the different factors that affect the electrokinetic behavior of sulfide minerals.

Fig. 2 presents the zeta potential of chalcopyrite as a function of $\mathrm{pH}$ in the absence and presence of an initial concentration of $50 \mathrm{~g} / \mathrm{t}$ of $\alpha$-D-glucose, bovine serum albumin, sodium salt of humic acid, biosolids or Aero 6697 promoter. As can be seen in this figure, biosolids as well as all the other chemicals used in this investigation 


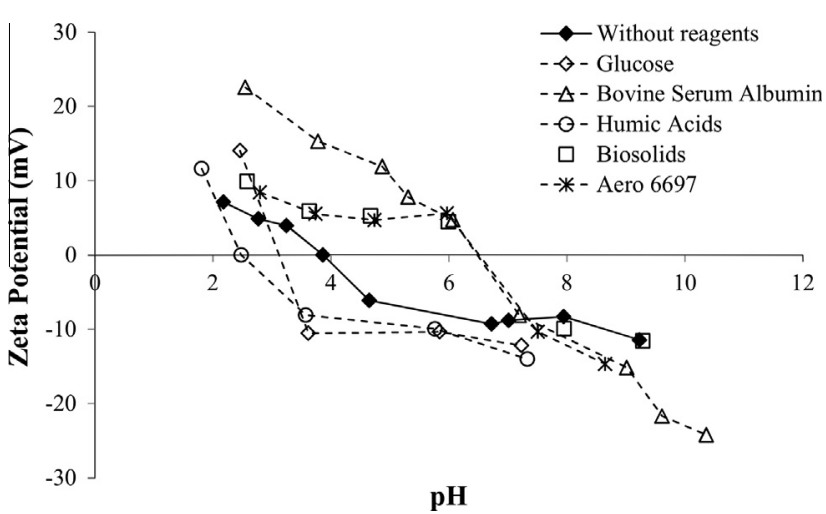

Fig. 2. The zeta potential of chalcopyrite in the absence and presence of an initial concentration of $50 \mathrm{~g} / \mathrm{t}$ glucose, bovine serum albumin, sodium salt of humic acids, biosolids or Aero 6697. Figure shows the average value $(n \geqslant 20)$ and standard error is within the symbols. Lines not necessarily represent linear trends.

shift the isoelectric point of chalcopyrite. With the initial concentration of biosolids, bovine serum albumin or Aero 6697 used in this research work, the isoelectric point of chalcopyrite occurs at $\mathrm{pH}$ 6.5. At this same concentration of glucose and sodium salt of humic acid, the IEP of chalcopyrite occurs at $\mathrm{pH} 3$ and $\mathrm{pH} 2.5$, respectively.

The sodium salt of humic acid makes the zeta potential of chalcopyrite more negative. Because the molecular structure of this organic compound contains carboxylic acid functional groups (von Wandruszka, 2000), whose pKa occurs at about pH 4, the more negative zeta potential of chalcopyrite in the presence of the sodium salt of humic acid may be associated to the adsorption of the anionic carboxylate functional groups of the humic compound on the metal sites of chalcopyrite. Pandey et al. (2000) have reported that both $\mathrm{Cu}$ (II) and Fe (II) form coordination complexes with humic acids.

Previous studies have revealed that in a copper sulfide ore froth flotation plant, total or partial replacement of the main industrial collector (i.e., xanthate) by humic acids is possible (Reyes-Bozo et al., 2014a). At laboratory scale, humic acid and a mixture of humic acid and industrial collector give similar metallurgical indicators, namely copper recovery and grade of the concentrate. Further, humic acids exhibit similar collector ability for chalcopyrite and molybdenite as that of an industrial collector reagent (for example, Aero 6697 promoter or a xanthate type collector) whereas biosolids show more affinity for pyrite (Reyes-Bozo et al., 2014b).

Therefore, the effect of the initial concentration of the sodium salt of humic acids on the zeta potential of chalcopyrite, molybdenite and pyrite was evaluated by conditioning the mineral with $50 \mathrm{~g} / \mathrm{t}$ and $500 \mathrm{~g} / \mathrm{t}$ of humic acids. This second dosage was used to investigate the effect that an excess of this chemical would have on the zeta potential of the sulfide minerals used in this research work.

Fig. 3 shows the zeta potential of chalcopyrite when two different initial dosages of sodium salt of humic acid are added. A ten-fold increase in the initial concentration of humic acids shifts the isoelectric point of chalcopyrite below $\mathrm{pH} 2$ and makes its zeta potential significantly more negative between $\mathrm{pH} 3$ and $\mathrm{pH} 10$. Again, this significant increase of the negative zeta potential of chalcopyrite in the presence of $500 \mathrm{~g} / \mathrm{t}$ of sodium salt of humic acid seems to be related to the adsorption of the carboxylate functional groups of the humic compound on the copper and iron sites of chalcopyrite. Laskowski and Yu (1994) have also reported that the adsorption of humic acids changes the zeta potential of a mineral, making it more negative.

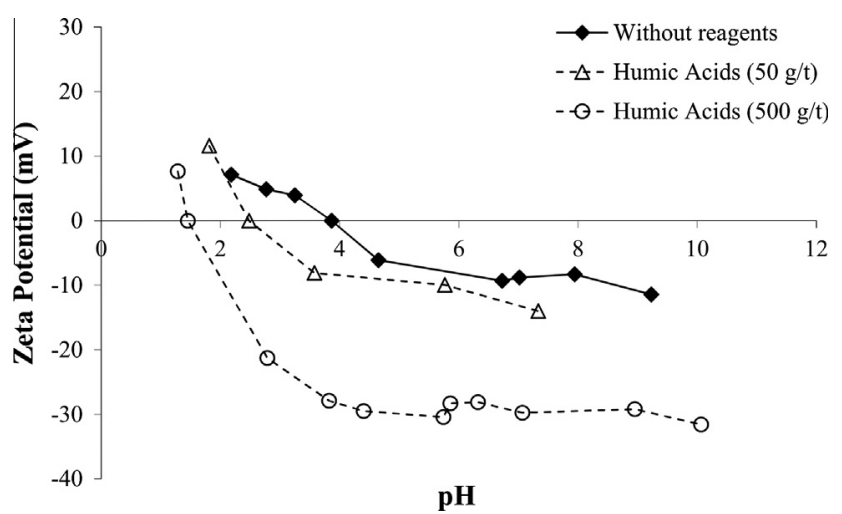

Fig. 3. The zeta potential of chalcopyrite as a function of $\mathrm{pH}$ in the absence and the presence of two different initial dosages of sodium salt of humic acids: $50 \mathrm{~g} / \mathrm{t}$ and $500 \mathrm{~g} / \mathrm{t}$. Figure shows the average value $(n \geqslant 20)$ and standard error is within the symbols. Lines not necessarily represent linear trends.

Fig. 4 presents the zeta potential of molybdenite as a function of $\mathrm{pH}$, when a $50 \mathrm{~g} / \mathrm{t}$ dosage of $\alpha$-D-glucose, bovine serum albumin, sodium salt of humic acid, biosolids or Aero 6697 promoter is added. Only the sodium salt of humic acid has a significant effect on the zeta potential of molybdenite, shifting the isoelectric point from $\mathrm{pH} 9.1$ to $\mathrm{pH}$ 3.6. This value of the IEP of molybdenite in the presence of the sodium salt of humic acid is very close to the $\mathrm{pKa}$ of carboxylic acid, namely about $\mathrm{pH} 4$. The negative zeta potential of molybdenite in the presence of humic acid suggests the adsorption of humic molecules, through their carboxylate anionic functional groups, at molybdenum surface sites.

According to the zeta potential results presented in Fig. 4, Aero 6697 promoter does not interact strongly with molybdenite surfaces. This electrokinetic behavior of molybdenite correlates well with industrial flotation results that indicate that the reagent Aero 6697 has greater affinity and selectivity for copper-containing species (Thomas, 2010).

Fig. 5 shows that the addition of $500 \mathrm{~g} / \mathrm{t}$ of sodium salt of humic acid shifts the isoelectric point of molybdenite to a more acid $\mathrm{pH}$ : to about $\mathrm{pH}$ 2. Similar to the zeta potential of chalcopyrite under these conditions, the adsorption of humic molecules makes the zeta potential of molybdenite significantly more negative in the whole range of $\mathrm{pH}$ investigated. These zeta potential results clearly indicate that humic molecules have a strong affinity for molybdenite surfaces, and that their adsorption onto molybdenite seems to

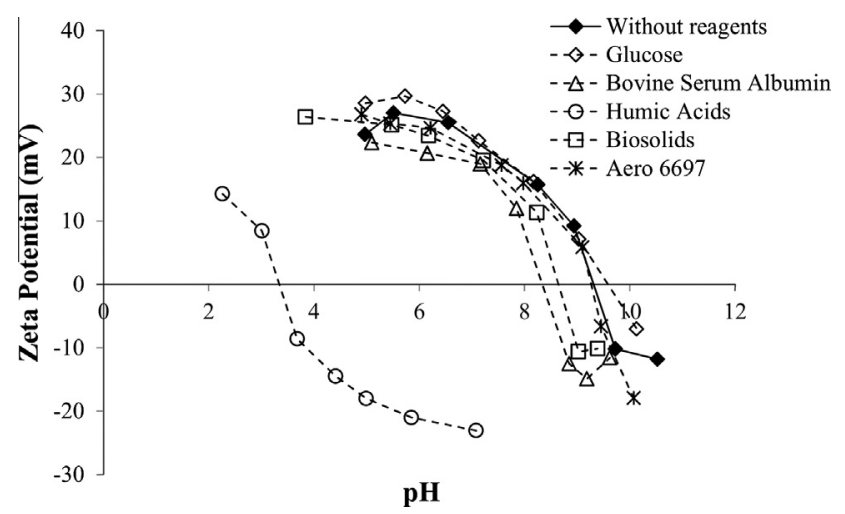

Fig. 4. The zeta potential of molybdenite as a function of $\mathrm{pH}$ in the absence and the presence of glucose, bovine serum albumin, sodium salt of humic acid, biosolids and Aero 6697, all at an initial dosage of $50 \mathrm{~g} / \mathrm{t}$. Figure shows the average value $(n \geqslant 20)$ and standard error is within the symbols. Lines not necessarily represent linear trends. 


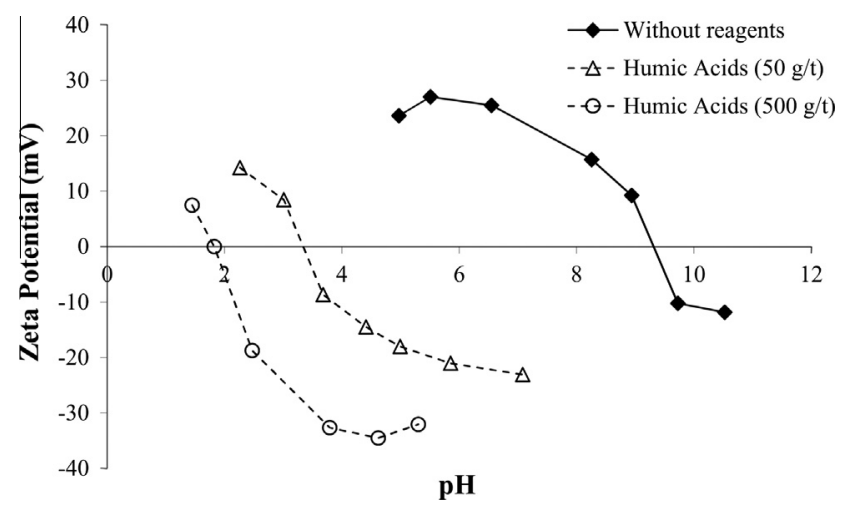

Fig. 5. The zeta potential of molybdenite as a function of $\mathrm{pH}$ in the absence and the presence of two different initial dosages of sodium salt of humic acid: $50 \mathrm{~g} / \mathrm{t}$ and $500 \mathrm{~g} / \mathrm{t}$. Figure shows the average value $(n \geqslant 20)$ and standard error is within the symbols. Lines not necessarily represent linear trends.

take place through the interaction of the carboxylate anionic functional groups with molybdenum surface sites.

Fig. 6 presents the zeta potential of pyrite as a function of $\mathrm{pH}$ in the absence and the presence of an initial concentration of $50 \mathrm{~g} / \mathrm{t}$ $\alpha$-D-glucose, bovine serum albumin, sodium salt of humic acid, biosolids or Aero 6697 promoter. The results shown in Fig. 6 indicate that the zeta potential of pyrite becomes slightly more negative between $\mathrm{pH} 7$ and $\mathrm{pH} 10$ when this dosage of biosolids and chemical compounds is used. These results suggest a poor affinity between pyrite surfaces and these compounds, unlike the zeta potential of chalcopyrite under the same conditions.

When the initial dosage of the sodium salt of humic acid is increased from $50 \mathrm{~g} / \mathrm{t}$ to $500 \mathrm{~g} / \mathrm{t}$, Fig. 7 shows that the isoelectric point of pyrite shifts to a significantly more acid $\mathrm{pH}$, namely about $\mathrm{pH} 2$. Similar to the zeta potential of chalcopyrite and molybdenite under the same conditions, this initial dosage of sodium salt of humic acid makes the zeta potential of pyrite more negative between $\mathrm{pH} 2$ and $\mathrm{pH}$ 7. These results suggest the adsorption of humic acid on pyrite, most likely through the interaction of the anionic carboxylate functional groups with the iron surface sites.

\subsection{Fourier transform infrared spectroscopy (FTIR) analyses}

FTIR spectroscopy was used to characterize chalcopyrite, molybdenite and pyrite before and after conditioning in solutions of biosolids, $\alpha$-D-glucose, bovine serum albumin, sodium salt of

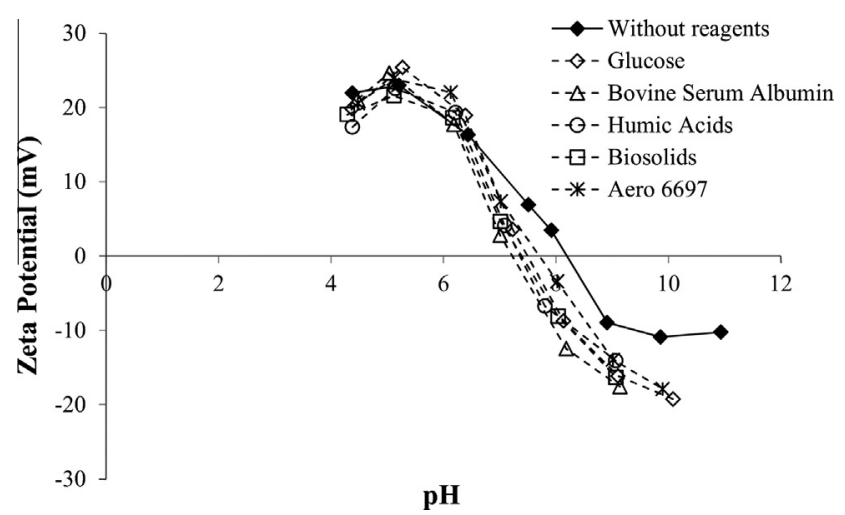

Fig. 6. The zeta potential of pyrite as a function of $\mathrm{pH}$ in the absence and the presence of an initial concentration of $50 \mathrm{~g} / \mathrm{t}$ glucose, bovine serum albumin, sodium salt of humic acid, biosolids or Aero 6697. Figure shows the average value $(n \geqslant 20)$ and standard error is within the symbols. Lines not necessarily represent linear trends.

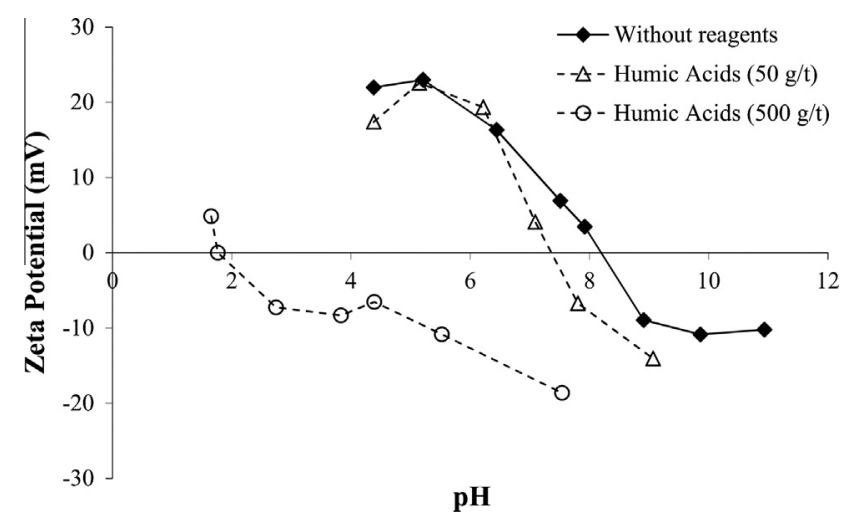

Fig. 7. The zeta potential of pyrite as a function of $\mathrm{pH}$ in the absence and presence of two different initial concentrations of sodium salt of humic acid: $50 \mathrm{~g} / \mathrm{t}$ and $500 \mathrm{~g} / \mathrm{t}$. Figure shows the average value $(n \geqslant 20)$ and standard error is within the symbols. Lines not necessarily represent linear trends.

humic acid, or Aero 6697 in order to gain a better understanding of the interaction of these sulfide minerals with these different compounds.

Discussion and interpretation of FTIR spectra are based on the peaks assigned to the different sulfate species reported in the literature. As described by Steger and Desjardins (1978) and Sutherland and Wark (1955), sulfates can be formed from the oxidation of chalcopyrite, molybdenite and pyrite. Pure metallic signatures of mineral samples cannot be observed on the wave-range considered in the present study since the vibrations of metallic components tend to be present at the lower energetic range (molybdenite $\mathrm{MoS}_{2} \sim 470 \mathrm{~cm}^{-1}$ (Liu et al., 2012); pyrite $\mathrm{FeS}_{2} \sim 420 \mathrm{~cm}^{-1}$ (White and Roy, 1964)). Nevertheless, as will be described on the following section, sulfate signatures from chalcopyrite, molybdenite and pyrite have been identified and could be used for analyses that, as focused on in the present work, tend to report the presence of molecular interactions involved among the reagents used and the surfaces of the minerals under consideration. For example, the adsorption of humic substances on pyrite was studied. The interaction between humic acid and pyrite was irreversible and their adsorption blocked the electrochemical activity of pyrite (Acai et al., 2009). Therefore, biosolids that contain humic substances should interact with sulfides mineral, such as pyrite. Furthermore, given the organic nature of the reagents evaluated, the FTIR wave-range considered $\left(4000-500 \mathrm{~cm}^{-1}\right)$ is ideal for identifying chemical interactions, by evaluating the formation of metal-organic species over the mineral surfaces.

Figs. 8-10 show the FTIR results obtained by using the procedure previously described. As observed in the figures, $\mathrm{CuFeS}_{2}$ and $\mathrm{FeS}_{2}$ pure samples spectra (upper spectrum in each corresponding figure) indicate the presence of pure sulfates, water, ammonium ions, carbonate and/or quartz. In the case of $\mathrm{MoS}_{2}$ concentrate, its FTIR spectrum indicates the presence of water and sulfates only.

As can be observed in Figs. 8-10, between $1250 \mathrm{~cm}^{-1}$ and $900 \mathrm{~cm}^{-1}$ there is a considerable concentration of signals related to sulfates which could come from hydroxyl ferric sulfate, ferric sulfate, hydrated ferric sulfate, ferrous sulfate, ferric sulfate clusters, hydrated ferrous sulfate, and hydrated ferrous sulfates for minerals containing iron ions (Derycke et al., 2013); sulfates with copper ions also produce vibrations in the similar range and given the relatively small differences in electronegativity, vibrations could overlap with those from sulfates with iron ions, especially with those with the same oxidation state.

In the present analyses, only the most intense signals were considered and compared with the work of Derycke et al. (2013), Haber (1977), and Miller and Wilkins (1952). Derycke et al. 


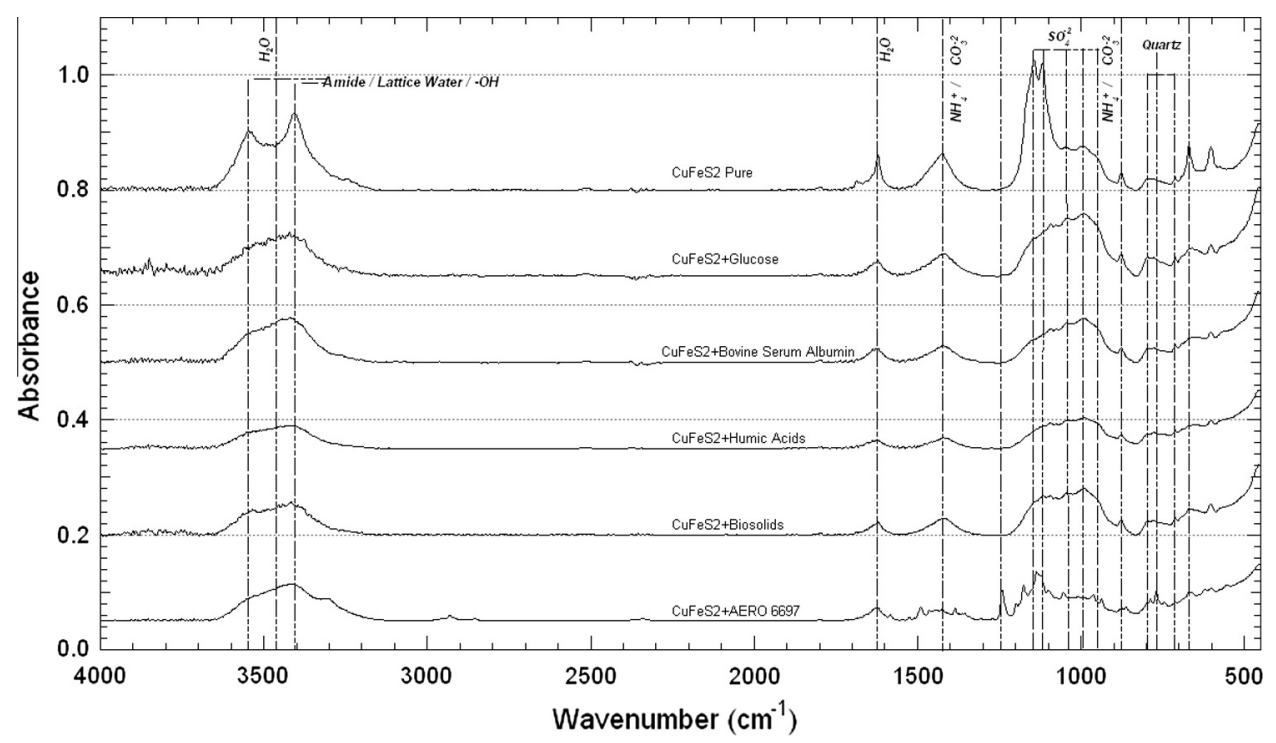

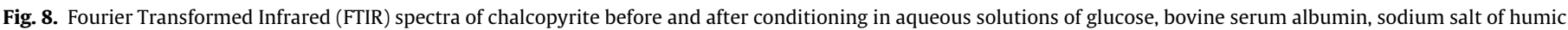
acid, biosolids or Aero 6697 promoter at an initial concentration of $50 \mathrm{~g} / \mathrm{t}$.

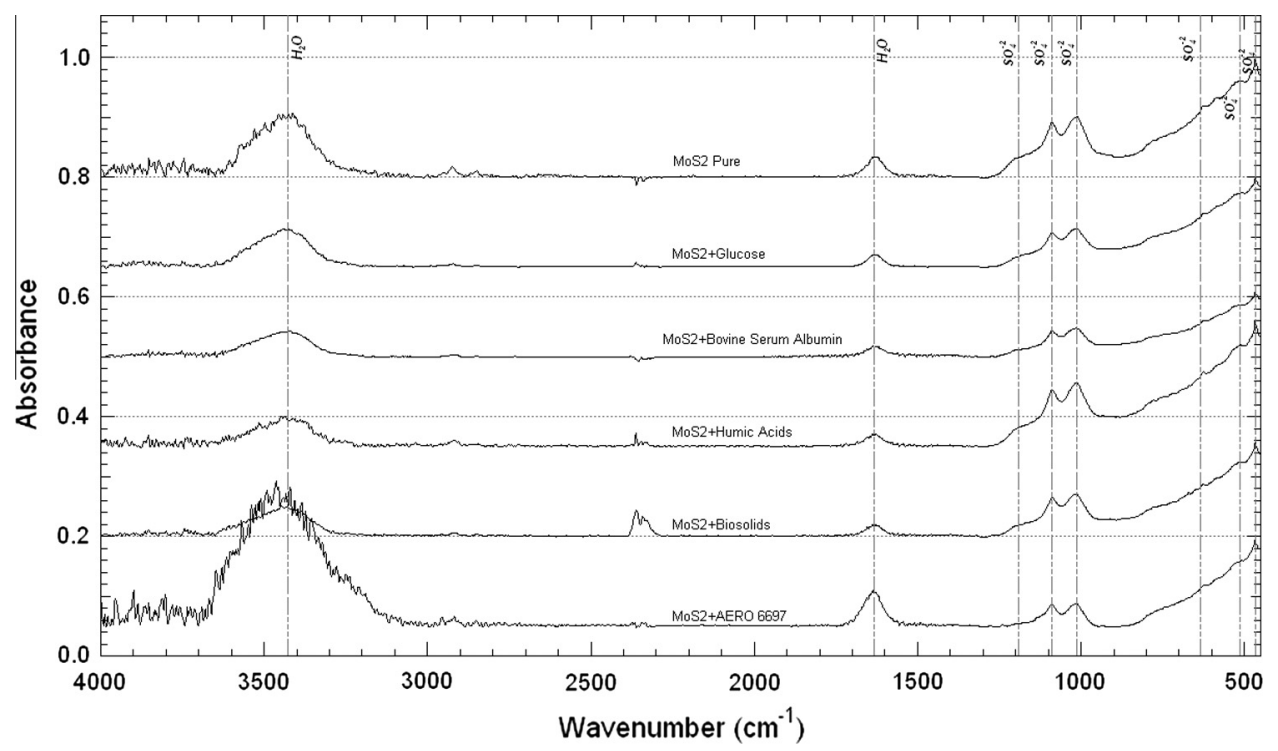

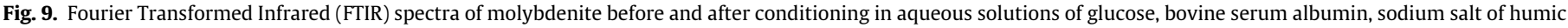
acid, biosolids or Aero 6697 promoter at an initial concentration of $50 \mathrm{~g} / \mathrm{t}$.

(2013) have considered only sulfate ion interactions with iron ions whereas Haber (1977) and Miller and Wilkins (1952) have also considered the interaction of sulfate ions with surface copper ions.

As observed in Fig. 8, which corresponds to chalcopyrite, the stronger signals could correspond to ferrous sulfate and hydrated ferric sulfate $\left(1147 \mathrm{~cm}^{-1}\right)$; ferrous sulfate, ferric sulfate, and hydrated copper sulfate $\left(1120 \mathrm{~cm}^{-1}\right)$; ferric sulfate $\left(1040 \mathrm{~cm}^{-1}\right)$; anhydrous ferrous sulfate $\left(993 \mathrm{~cm}^{-1}\right)$; and hydrated ferrous sulfate and copper sulfate $\left(960 \mathrm{~cm}^{-1}\right)$. For the $\mathrm{FeS}_{2}$ samples, the main peaks correspond to hydroxyl ferric sulfate $\left(1230 \mathrm{~cm}^{-1}\right)$, ferric sulfate $\left(1176 \mathrm{~cm}^{-1}\right)$, ferric sulfate cluster $\left(1140 \mathrm{~cm}^{-1}\right)$, ferrous sulfate $\left(1089 \mathrm{~cm}^{-1}\right)$ and hydrated ferric sulfate $1020\left(\mathrm{~cm}^{-1}\right)$. Non-hydrated ferric sulfates possess strong vibrations in the $1200 \mathrm{~cm}^{-1}$ range, and, as observed in Fig. 8, there is almost no existence of these vibrations. The lack of these signatures implies that signatures should preferentially come from hydrated species and ferric sulfates. On the other hand, Figs. 9 and 10 show the presence of vibrations in this range, which supports the existence of lower hydrations of sulfate species. Copper sulfates (hydrated and non-hydrated) also show strong vibrations in the $1200 \mathrm{~cm}^{-1}$ range. The small presence of these vibrations implies that copper species could show higher resistance to oxidation, which is supported by documented information of oxidation of mineralogical sulfide species (Steger and Desjardins, 1978; Sutherland and Wark, 1955) which describes a higher oxidation tendency of species with iron ions. Further, for the $\mathrm{MoS}_{2}$ sample, only an analogical assignation was performed, but the described signals correspond to sulfates.

Once the individual spectra were analyzed, the pure $\mathrm{CuFeS}_{2}$ pictogram described broad bands, which could be related to metallic amides or carbonate. Metallic amides could be related to impurities present in the treated samples. Nevertheless, since pure components also present these vibrations, the possible existence of metallic amides vibrations assignation are relatively smaller. As presented in the work of Derycke et al. (2013), vibrations in the 


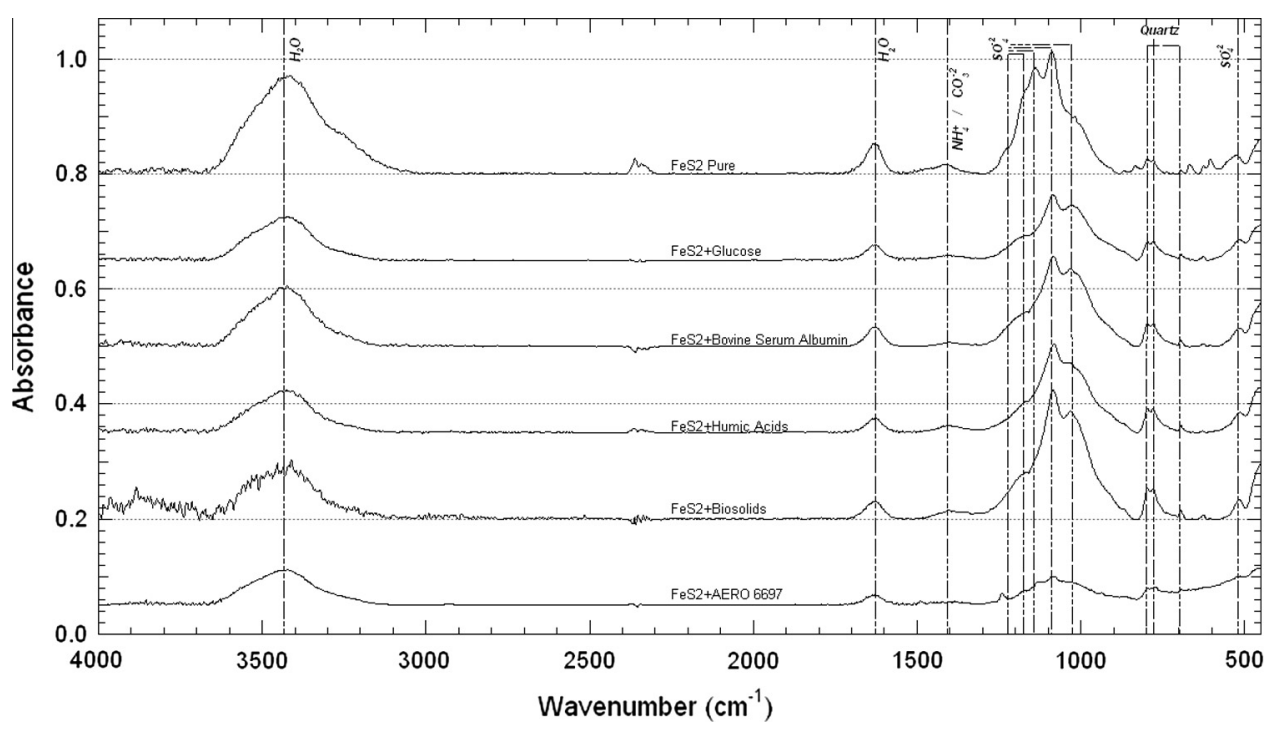

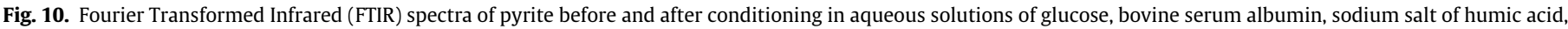
biosolids or Aero 6697 promoter at an initial concentration of $50 \mathrm{~g} / \mathrm{t}$.

range of $3550 \mathrm{~cm}^{-1}$ and $3405 \mathrm{~cm}^{-1}$ could come from lattice water or other hydroxyl groups. These vibrations are considerable removed from after treatment which could imply a considerable removal of hydroxyl groups from lattice structures or hydrated species. Additionally, the signals related to carbonate (or metallic amides) $\left(\sim 1420 \mathrm{~cm}^{-1}\right)$ were partially eliminated. In the case of pure $\mathrm{FeS}_{2}$, the shoulders observed in the same regions also indicate the presence of amides ammonium ions, but their signals intensity are considerably smaller (they follow the same tendency after treatments with the different solutions).

The bottom spectra of each figure shows the result obtained after the samples were treated with the industrial chemical collector (Aero 6697 promoter, Cytec). As observed, and visually compared with the other treatments (middle spectra obtained with glucose, bovine serum albumin, humic acids and biosolids), the industrial collector showed a considerable modification of the concentration of sulfates of the treated minerals, with the exception of $\mathrm{MoS}_{2}$. This behavior was expected since in industrial systems the reagent Aero 6697 promoter has greater affinity for copper-containing species with respect to new reagents evaluated (Thomas, 2010).

On the other hand, treatment with glucose, bovine serum albumin, sodium salt of humic acid and biosolids also described a reduction of signals, specifically, in the case of $\mathrm{FeS}_{2}$, the most affected signals were the ferric sulfate cluster and the ferric sulfate. However for the $\mathrm{CuFeS}_{2}$, the hydrated ferric sulfate $\left(1147 \mathrm{~cm}^{-1}\right)$ and the ferrous and ferric sulfate $\left(1120 \mathrm{~cm}^{-1}\right)$ signals intensities were the most different. Finally, the $\mathrm{MoS}_{2}$ sample did not describe a specific reduction of sulfate signals; instead, a full reduction of each signal was observed. This behavior indicates that all the collectors can chemically or physically interact with the surface of the sulfide mineral evaluated.

A full comparison of the areas between the pure samples and the treated samples was performed. Table 1 shows the results obtained and gives the percentage of extraction of the sulfates considered between the $1280 \mathrm{~cm}^{-1}$ to the $900 \mathrm{~cm}^{-1}$. As observed in the table, the industrial chemical collector produced the highest degree of sulfate extraction, while the other reagents showed smaller capabilities of extraction but their selection depends of the sulfate nature. Biosolids showed a relative increase (negative value). This gas correlated to a modification of the nature of the sulfates to a more intense ferrous sulfate, which could have a higher absorption IR coefficient.
Table 1

Percentages of sulfates signal modification by the different treatments.

\begin{tabular}{lllc}
\hline Collectors & \multicolumn{2}{l}{ Sulfide minerals } & \\
\cline { 2 - 4 } & $\begin{array}{l}\text { Chalcopyrite } \\
\left(\mathrm{CuFeS}_{2}\right)\end{array}$ & $\begin{array}{l}\text { Molybdenite } \\
\left(\mathrm{MoS}_{2}\right)\end{array}$ & $\begin{array}{c}\text { Pyrite } \\
\left(\mathrm{FeS}_{2}\right)\end{array}$ \\
\hline Pure & 0.0 & 0.0 & 0.0 \\
Aero 6697 promoter & 52.2 & 62.4 & 72.1 \\
$\alpha$-D-glucose & 19.5 & 48.7 & 42.7 \\
Bovine serum & 46.4 & 63.1 & 20.9 \\
$\quad$ albumin & 60.2 & 13.6 & 28.8 \\
Humic Acids & 40.1 & 40.6 & -5.9 \\
Biosolids & & & \\
\hline
\end{tabular}

\section{Conclusions}

The interaction of biosolids and synthetic compounds representative of their main components, namely $\alpha$-D-glucose, bovine serum albumin and sodium salt of humic acid, as well as Aero 6697 promoter, with the surfaces of chalcopyrite, molybdenite and pyrite was investigated through zeta potential measurements and Fourier transform infrared spectroscopy. Zeta potential results show that all of these compounds modify the electrokinetic behavior of these sulfide minerals, and especially in the case of chalcopyrite and molybdenite. In particular, the sodium salt of humic acid at an initial concentration of $50 \mathrm{~g} / \mathrm{t}$, makes the zeta potential of chalcopyrite and molybdenite significantly more negative. This electrokinetic behavior may be associated to the adsorption of the anionic carboxylate functional groups of the humic compound on the metal sites of sulfide minerals studied. FTIR spectra indicate that the different compounds used in this research work interact with the metallic surface sites of chalcopyrite, molybdenite and pyrite, as deduced by the reduction of the corresponding sulfate signatures.

\section{Acknowledgments}

This research was funded by Chile's Conicyt program through the National Fund for Scientific and Technological Research (Fondecyt) via No. 11121159 Project and support came from a research grant from Universidad Andres Bello, Project DI-721-15/R (L. Reyes-Bozo). The grant to Reyes-Bozo, L. obtained from Universidad de Castilla-La Mancha ("Ayudas para estancias 
de investigadores invitados en la UCLM para el año 2015, DOCM $18 / 11 / 2014 ")$ was greatly appreciated. Biosolids and industrial chemical collectors were provided by Essbio (G. Wolf and J. Vásquez) and Cytec Chile (R. Capanema), respectively. Further, chalcopyrite, pyrite and molybdenite samples were provided by Anglo American Chile and Molymet Chile (J. Gacitúa).

\section{References}

Acai, P., Sorrenti, E., Gorner, T., Polakovic, M., Kongolo, M., de Donato, P., 2009. Pyrite passivation by humic acid investigated by inverse liquid chromatography Colloids Surf. A: Physicochem. Eng. Aspects 337, 39-46.

Baham, J., Sposito, G., 1982. Chemistry of water-soluble, metal-complexing ligands extracted from an anaerobically-digested sewage sludge. J. Environ. Qual. 12 (1), 96-100.

Bulatovic, M., 2007. Handbook of Flotation Reagents: Chemistry, Theory and Practice: Volume 1: Flotation of Sulfide Ores, first ed. Elsevier Science, The Netherlands.

Cochilco, Chilean Copper Commission, 2013: Inversión en la minería Chilena: Cartera de Proyectos 2013-2021, Santiago, Chile.

Cochilco, Chilean Copper Commission, 2012. Yearbook: Copper and other Minera Statistics 1993-2012, Santiago, Chile.

Das, K.K., Pradip, Natarajan, K.A., 1997. The effect of constituent metal ion son the electrokinetics of chalcopyrite. J. Colloid Interface Sci. 196, 1-11.

Derycke, V., Kongolo, M., Benzaazoua, M., Mallet, M., Barrès, O., De Donato, P. Bussière, B., Mermillod-Blondin, R., 2013. Surface chemical characterization of different pyrite size fractions for flotation purposes. Int. J. Miner. Process. 118 $1-14$.

Escudey, M., Galindo, G., Avendaño, K., Borchardt, D., Chang, A., Briceño, M., 2004. Distribution of phosphorus forms in Chilean soils and sewage sludge by chemical fractionation and ${ }^{31}$ P-NMR. J. Chil. Chem. Soc. 49 (2), 107-110.

Eskicioglu, C., Kennedy, K.J., Droste, R.L., 2006. Characterization of soluble organic matter of waste activated sludge before and after thermal pretreatment. Water Res, 40, 3725-3736.

Fuerstenau, D.W., Mishra, R.K., 1980. On the mechanism of pyrite flotation with xanthate collectors. In: Jones, M.J. (Ed.), Complex Sulphide Ores. Institution of Mining and Metallurgy, London, pp. 271-278.

Gaines, V.R., Skinner, W.C., Foord, E.E., Mason, B., Rosenzweig, A., 1997. Dana’s New Mineralogy, eighth ed. John Wiley \& Sons Inc.

Gaudin, A.M., Sun, S.C., 1946. Correlation between mineral behavior in cataphoresis and flotation. Trans. AIME 169, 347-362.

Gil-Llambías, F.J., Escudey Castro, M., Bouyssieres McLeod, L., 1984. Electrophoretic characterization of unsupported Co-Mo sulfided catalysts prepared by different methods. J. Catal. 88 (222), 224.

Haber, V., 1977. Study of the amorphous product of dehydration of copper(II) sulfate pentahydrate. Chem. Zvesti. 31 (2), 190-196.

Healy, T.W., Fuerstenau, D.W., 2007. The isoelectric point/point-of zero-charge of interfaces formed by aqueous solutions and nonpolar solids, liquids, and gases. J. Colloid Interface Sci. 309, 183-188.

JCPDS-ICDD, 2009. PDF crystallographic database. JCPDS-ICDD Powder Diffraction File (PDF-2), International Centre for Diffraction Data, Newtown square, PA USA
Laskowski, J.S., Yu, Z., 1994. The effect of humic acids on the emulsion flotation of inherently hydrophobic minerals. In: III Latin American Congress on Froth Flotation. Universidad de Concepción, Concepción-Chile.

Liu, J.C., Huang, C.P., 1992. Electrokinetic characteristics of some metal sulfidewater interfaces, Langmuir 8, 1851-1856.

Liu, S., Zhang, X., Shao, H., Xu, J., Chen, F., Feng, Y., 2012. Preparation of $\mathrm{MoS}_{2}$ nanofibers by electrospinning. Mater. Lett. 73, 223-225.

Miller, F.A., Wilkins, C.H., 1952. Infrared spectra and characteristics frequencies of inorganic ions. Anal. Chem. 24 (8), 1253-1294.

Mitchell, T.K., Nguyen, A.V., Evans, G.M., 2005. Heterocoagulation of chalcopyrite and pyrite minerals in flotation separation. Adv. Colloid Interface 114-115, 227-237.

Pandey, A.K., Pandey, S.D., Misra, V., Viswanathan, P.N., 1999. Formation of soluble complexes of metals with humic acid and its environmental significance. Chem. Ecol. 16 (4), 269-282.

Pandey, A.K., Pandey, S.D., Misra, V., 2000. Stability constants of metal-humic acid complexes and its role in environmental detoxification. Ecotox. Environ. Safe. 47, 195-200.

Parnaudeau, V., Dignac, M.-F., 2007. The organic matter composition of various wastewater sludges and their neutral detergent fractions as revealed by pyrolysis-GC/MS. J. Anal. Appl. Pyrol. 78, 140-152.

Patra, P., Natarajan, K.A., 2006. Surface chemical studies on selective separation of pyrite and galena in the presence of bacterial cells and metabolic products of Paenibacillus polymyxa. J. Colloid Interface Sci. 298, 720-729.

Ras, M., Girbal-Neuhauser, E., Paul, E., Spérandio, M., Lefebvre, D., 2008. Protein extraction from activated sludge: an analytical approach. Water Res. 42, 18671878.

Rath, R.K., Subramanian, S., Sivanandam, V., Pradeep, T., 2001. Studies on the interaction of guar gum with chalcopyrite. Can. Metall. Quart. 40 (1), 1-12.

Reyes-Bozo, L., Herrera-Urbina, R., Godoy-Faúndez, A., Sáez-Navarrete, C., Herrera, M., Ginocchio, R., 2011a. Uso de biosólidos como reactivo espumante en procesos de flotación: caracterización física y química. Dyna 78 (167), 66-73.

Reyes-Bozo, L., Herrera-Urbina, R. Escudey, M. Godoy-Faúndez, A., Sáez-Navarrete, C., Herrera, M., Ginocchio, R., 2011b. Role of biosolids on hydrophobic properties of sulfide ores. Int. J. Miner. Process. 100 (3-4), 124-129.

Reyes-Bozo, L., Godoy-Faúndez, A., Higueras, P., Herrera-Urbina, R., Salazar, J.L., Vyhmeister, E., Valdés-González, H., Antizar-Ladislao, B., 2014a. Greening Chilean mining operations through industrial ecology strategies. J. Clean. Prod. 84, 671-679.

Reyes-Bozo, L., Higueras, P. Godoy-Faúndez, A., Sobarzo, F. Sáez-Navarrete, C. Vásquez-Bestagno, J., Herrera-Urbina, R., 2014b. Assessment of the floatability of chalcopyrite, molybdenite and pyrite using biosolids and their main components as collectors for greening the froth flotation of copper sulphide ores. Miner. Eng. 64, 38-43.

Sadzawka, A., Carrasco, M.A., Grez, R., Mora, M.L., Flores, H., Neaman, A., 2006. Métodos de Análisis Recomendados Para los Suelos de Chile. Instituto de Investigaciones Agropecuarias (INIA), Santiago, Chile.

Steger, H.F., Desjardins, L.E., 1978. Oxidation of sulphide minerals, 4. Pyrite, chalcopyrite and pyrrhotite. Chem. Geol. 23, 225-237.

Sutherland, K.L., Wark, I.W., 1955. Principles of Flotation. Australasian Institute of Mining and Metallurgy, Melbourne.

Thomas, W., 2010. Mining Chemical Handbook. Cytec industries Inc., USA.

Von Wandruszka, R., 2000. Humic acids: their detergent qualities and potential uses in pollution remediation. Geochem. Trans. 2

White, W.B., Roy, R., 1964. Infrared spectra-crystal structure correlations: II. Comparison of simple polymorphic minerals. Am. Mineral. 49, 1670-1687. 